\title{
MEDISINUTDANNING UNDER UTVIKLING
}

\section{Som ved de fleste andre studiesteder i Norge har Norges teknisk-naturvitenskapelige universitet (NTNU)} i Trondheim en svært populær medisinutdanning. Likevel er studiestedet opptatt av hele tiden å forbedre og videreutvikle seg.
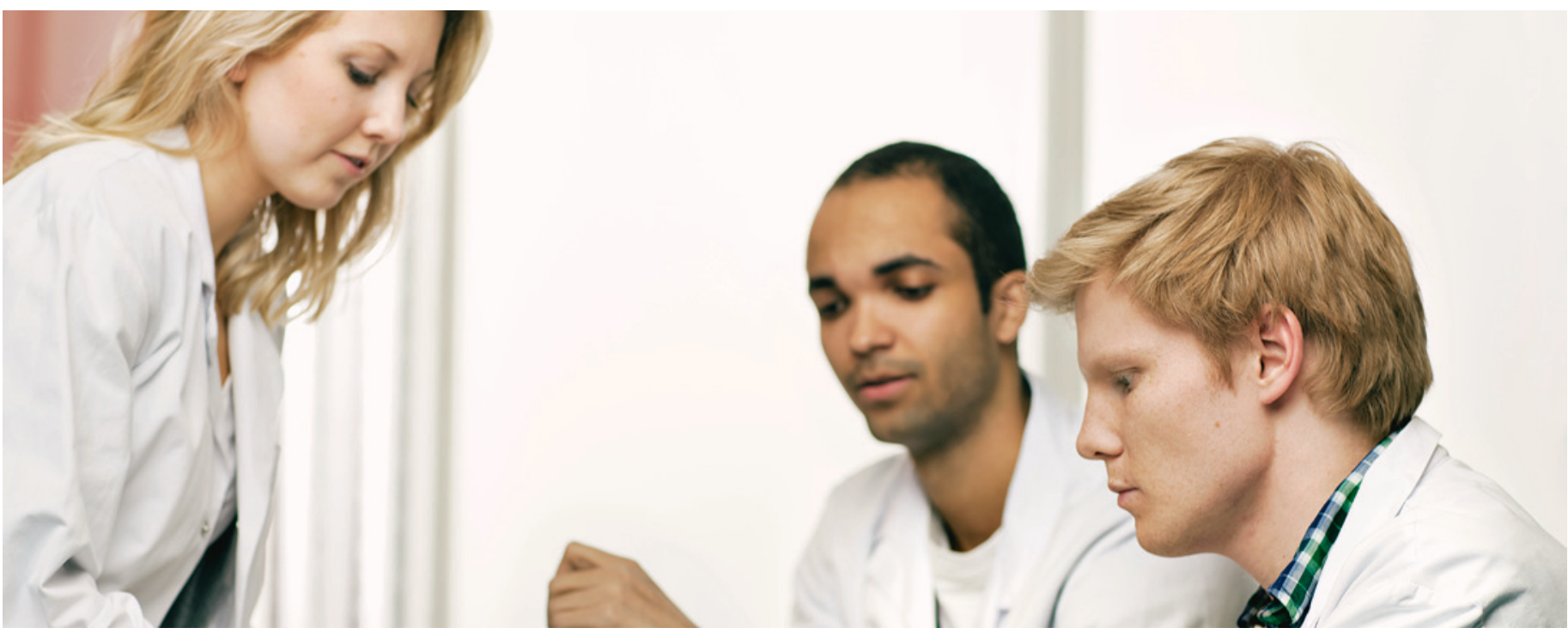

Studenter ved det medisinske fakultet på Norges teknisk-naturvitenskapelige universitet. Foto: Geir Mogen

Prosjektgruppen for gjennomgang av medisinstudiet leverte tidligere i høst en rapport med blant annet forslag til forbedringstiltak. Hensikten med rapporten var å se på ulike sider ved medisinstudiet, både på studieledelse og faglig kvalitet. Det understrekes at for å kunne gjøre forbedringer og videreutvikling av den faglige kvaliteten, må man først gjøre nødvendige endringer i studieledelsen.

\section{Konkrete forslag}

I rapporten konkluderer man med forskjellige forslag til forbedringer i studieledelse. Blant annet foreslår prosjektgruppen at Kontor for studieledelse og Pedagogisk lærings- og utdanningssenter skal samlokaliseres til to enheter i felles areal. Sistnevnte senter skal sikre bedre oppfølging og støtte til lærere ved Det medisinske fakultet.

I tillegg er det foreslått endringer i noen støttefunksjoner, som etablering av et ferdighetssenter, samlokalisert med Medisinsk SimulatorSenter, og videreutvikling av elektronisk timeplan.

\section{Endring i studieplanen}

I rapporten er det også forslag om innføring av nye fag $\mathrm{i}$ blant annet kommunikasjon og forebyggende og helsefremmende arbeid. I tillegg til å innføre nye fag, ønskes enkelte revisjoner av de eksisterende.

\section{Hviler ikke på laurbærene}

De siste årene har Norges teknisk-naturvitenskapelige universitet vært en av de mest populære studieplassene for medisinstudiet i Norge (SSB). I et blogginnlegg på Forskning.no skriver Stig A. Slørdahl, dekan ved Det medisinske fakultet ved Norges teknisk-naturvitenskapelige universitet, at det kan være utfordrende å være populær:

- Det kan fort bre seg en holdning om at det vi gjør, er best, og at vi ikke trenger å tenke på hva vi bør gjøre bedre. Utgangspunktet for arbeidet med en gjennomgang av medisinstudiet vårt har nettopp vært at det finnes mye rom for forbedring og at helsetjenesten har endret seg med nye behov for kompetanse hos de nyutdannede legene, skriver han på bloggen.

\section{Attraktivt studium}

Det tilbys medisinstudier ved fire av landets universiteter i Oslo, Trondheim, Bergen og Tromsø. Til sammen var det drøyt 600 planlagte studieplasser og over 12300 søkere ved høstens opptak. Norges teknisk-naturvitenskapelige universitet har totalt sett hatt flest søkere de siste årene, tett etterfulgt av Universitetet i Oslo. Tallene er henholdsvis 2514 og 2455 for høstopptaket i år (SSB).

\section{Elisabeth Jacobsen} Tidsskriftet

\section{«Det finnes mye rom for forbedring»}

